Volume 3, Issue 2, pages 203-214

\title{
The Effect of Water Impact on the Refrigerant Pipeline between Compressor and Condensor on COP and Efficiency of Cooling Machine
}

\author{
Wibowo Kusbandono ${ }^{1, *}$ \\ ${ }^{1}$ Department of Mechanical Engineering, Faculty of Science and \\ Technology, Sanata Dharma University, Yogyakarta, Indonesia \\ *Corresponding Author: bowo@usd.ac.id
}

(Received 04-11-2021; Revised 10-11-2021; Accepted 10-11-2021)

\begin{abstract}
The purpose of this research is (a) to design and assemble a steam compression cycle cooling machine using the main components on the market (b) to obtain the characteristics of the cooling engine, which includes the Coefficient of Performance (COP) and the efficiency of the cooling engine. The research was conducted experimentally in the laboratory. The refrigeration machine works by using a steam compression cycle, with the main components: a compressor, an evaporator, a capillary tube and a condenser. The compressor power is $1 / 6 \mathrm{PK}$, while the other main components are adjusted to the size of the compressor power. The refrigerant used is R134a. Variations of the research were carried out on the condition of the refrigerant pipe located between the compressor and condenser: (a) without being submerged in water (b) submerged in 0.50 liters of water and (c) submerged in 0.75 liters of water. The results of the study provide information that the water immersion in the refrigerant pipe which is located between the compressor and condenser affects the COP value and the efficiency of the refrigeration machine. Consecutively (1)
\end{abstract}




\section{International Journal of Applied Sciences and Smart Technologies}

Volume 3, Issue 2, pages 203-214

p-ISSN 2655-8564, e-ISSN 2685-9432

without being submerged in water, the COP value is 2.45 and the efficiency is 0.64 (2) submerged in liter of water, the COP value is 2.41 and the efficiency is 0.62 (3) submerged in liter of water, the value COP is 2.34 and efficiency is 0.60 .

Keywords: COP, efficiency, cooling engine, steam compression cycle, submerged in water

\section{Introduction}

A two-door refrigerator is one example of a cooling machine commonly used by housewives. A two-door refrigerator is a cooling machine that can be used to cool a variety of foodstuffs and various kinds of beverages and can be used to freeze food and water. The working temperature of the two-door refrigerator cooling machine is generally below $0^{\circ} \mathrm{C}$. The working temperature of the evaporator ranges from $-15^{\circ} \mathrm{C}$ until $-28^{\circ} \mathrm{C}$. In a two-door refrigerator, there are 2 rooms that have different functions, one room has a very low temperature, which functions to freeze food ingredients (freezer room), and the other room serves to cool or lower the temperature of various foodstuffs and beverages, without freezing.

In a two-door refrigerator, the process of freezing and cooling food ingredients is carried out by cold air circulated by a fan, passing through every food ingredient in the refrigerator. The circulated air is of very low temperature, which is obtained when air is passed through the evaporator. This air temperature is close to the working temperature of the evaporator. After passing through the evaporator, the air is flowed into the freezer chamber and then only flown into the cooling chamber. From the cooling chamber the air is recirculated through the evaporator and sent to the freezer again. Thus the air circulation takes place continuously. When the air passes through the evaporator, the water content in the air will be frozen and will become ice flowers that will stick to the evaporator. The air can contain moisture, because the refrigerator door is often opened. As time goes by, the ice in the evaporator is getting more and more or thicker so that it will interfere with the performance of the two-door refrigerator cooling machine. 


\section{International Journal of Applied Sciences and Smart Technologies}

Volume 3, Issue 2, pages 203-214

p-ISSN 2655-8564, e-ISSN 2685-9432

Therefore, these frosts must be removed, and immediately removed from the evaporator so that the performance of the refrigeration machine remains high.

In general, frost is removed by heating. After a certain period of time (about 7 hours), the electric heater attached to the evaporator will work and melt the ice flowers attached to the evaporator pipes into water. The water produced will fall and fall into the water reservoir, which is located at the bottom of the cooling machine. As time goes by, over time there will be more and more water in the reservoir and it will fill the water reservoir. This water reservoir is useless, and the water must be discarded, otherwise it will spill.

For some of the newer two-door refrigerators, the water stored in the water reservoir is removed in a way that does not bother the user. You do this by evaporating water in a water reservoir with heat energy. One way is, the water in the water reservoir is immersed in the high-temperature refrigerant pipeline, which is part of the cooling machine. The part that is immersed in the water is the refrigerant pipe which is located between the compressor and the condenser. With this method, the stored water can evaporate completely, so that refrigerator users are not bothered to dispose of stored water. Another way is, the water reservoir is heated by touching the surface of the compressor casing. The heat received by the reservoir is then used to estimate the water.

How to estimate the water in this reservoir is very interesting for the author to find out how the effect of the volume of soaking water on the characteristics of the refrigeration machine, when the refrigerant pipeline located between the compressor and the condenser is submerged in water. How is the effect of the immersion water on the COP and efficiency of the cooling machine? In this research, we refer to the references [1], [2], [3], [4], and [5].

\section{Research Methodology}

\section{Researched object}

The object under study is a refrigeration machine that works with a vapor compression cycle, with a hermetic compressor power of $1 / 6 \mathrm{hp}$, other main components such as: finned tube evaporator, pipe condenser with reinforcing radius and 
International Journal of Applied Sciences and Smart Technologies

Volume 3, Issue 2, pages 203-214

p-ISSN 2655-8564, e-ISSN 2685-9432

capillary tube, the size of which adjusts to the magnitude of the compressor power. All components are standard components obtained in the market. A schematic drawing of the tested cooling engine is presented in Figure 1.

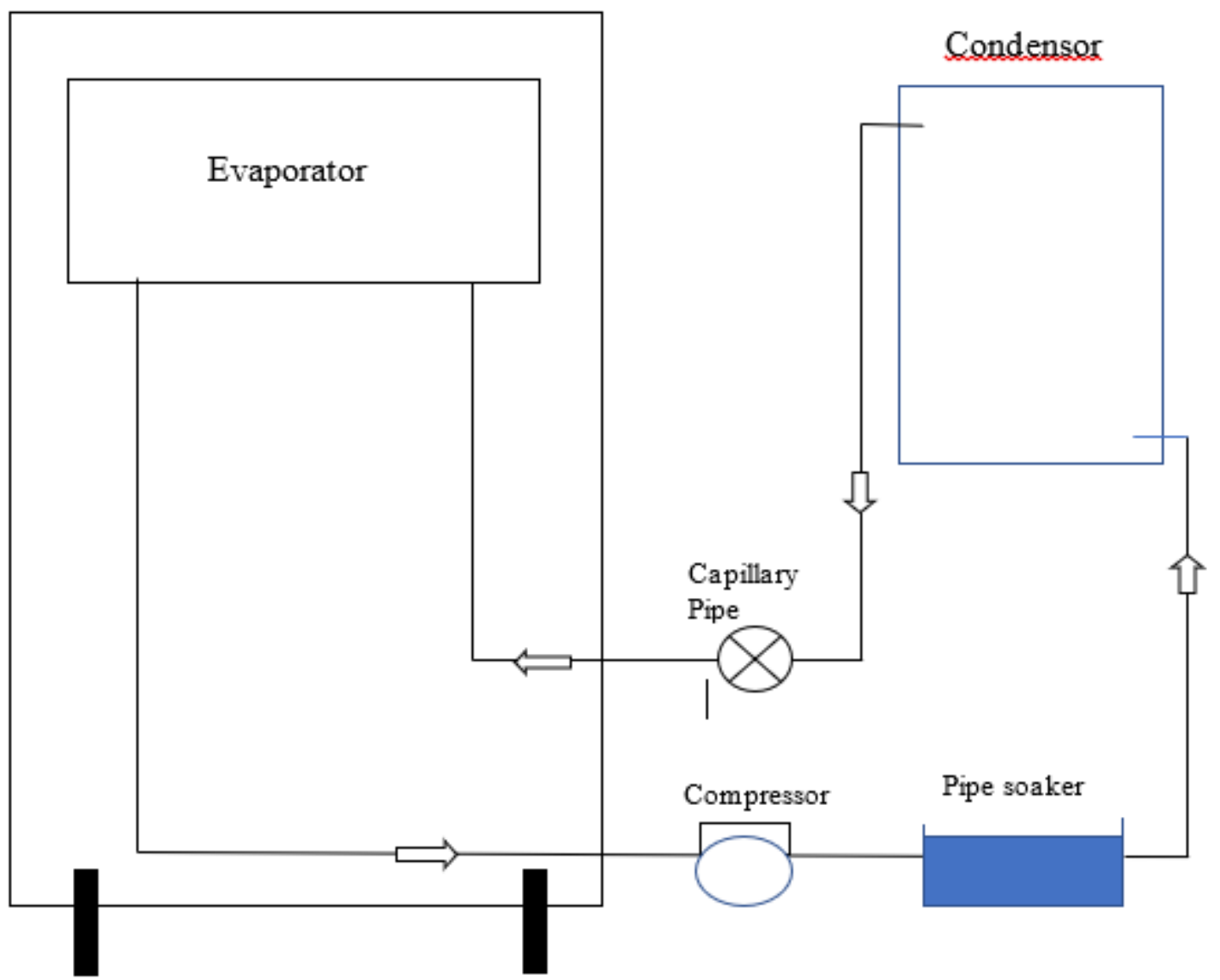

Figure 1. Schematic of the cooling machine under study. 


\section{International Journal of Applied Sciences and Smart Technologies}

Volume 3, Issue 2, pages 203-214

p-ISSN 2655-8564, e-ISSN 2685-9432

\section{Research Flow}

The research was conducted experimentally. The research flow is presented in Figure 2.

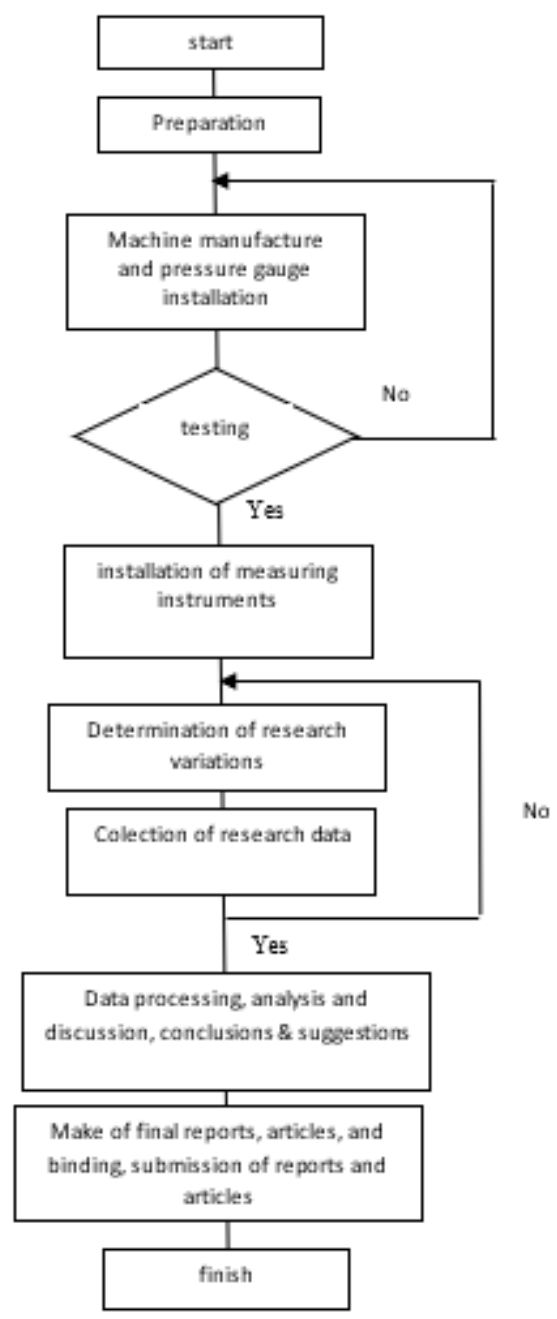

Figure 2. Research flow chart

\section{Research Variation}

The research was conducted by varying the volume of water used to immerse the refrigerant pipe located between the compressor and condenser (a) volume of water: 0 $\mathrm{ml}$ or without immersion (b) volume of water: 0.5 liters and (c) volume of water 0.75 liters. Variations are made to see the $C O P_{\text {actual }}$ and efficiency of the cooling machine. 


\section{International Journal of Applied Sciences and Smart Technologies}

Volume 3, Issue 2, pages 203-214

p-ISSN 2655-8564, e-ISSN 2685-9432

\section{Results and Discussion}

The results of the research and the results of data processing required to determine the characteristics of the cooling machine are presented in Table 1 to Table 3. The data presented is the result of recording data at 180 minutes, after the cooling machine is turned on/run. With the reason, that at that minute, the work of the machine can be considered "calm".

In the discussion of the results of this study, to facilitate data processing, the process of further cooling and further heating on the compression cycle is ignored. This is due to the difficulty of obtaining refrigerant properties such as the entropy and enthalpy of the refrigerant at high heat conditions. It is actually possible in other ways to obtain data on hot conditions (hot gas conditions) and further cold based on the P-h R134a diagram, but researchers have difficulty getting accurate and definite data that can be accounted for, because it is only based on estimates.

From the research that has been done, the cooling machine that is designed and assembled is able to work well as desired. Able to work continuously without jamming / dead machines or overheating. From the research data, the machine is able to provide a relatively very low working temperature of the evaporator, below $-23^{\circ} \mathrm{C}$. Likewise with the working temperature of the condenser, it can work at temperatures above the surrounding ambient temperature (above $37^{\circ} \mathrm{C}$ ).

Table 1. Working pressure and temperature of the evaporator and condenser

\begin{tabular}{|c|c|c|c|c|c|c|c|c|}
\hline \multirow{2}{*}{$\begin{array}{l}\text { Condition of } \\
\text { the pipe } \\
\text { between } \\
\text { compressor } \\
\text { and condenser }\end{array}$} & \multicolumn{2}{|c|}{$\begin{array}{l}\text { Evaporator } \\
\text { working } \\
\text { pressure }\end{array}$} & \multicolumn{2}{|c|}{$\begin{array}{l}\text { Condenser } \\
\text { working } \\
\text { pressure }\end{array}$} & \multicolumn{2}{|c|}{$\begin{array}{c}\text { Evaporator } \\
\text { working } \\
\text { temperature }\end{array}$} & \multicolumn{2}{|c|}{$\begin{array}{l}\text { Condenser } \\
\text { working } \\
\text { temperature }\end{array}$} \\
\hline & $\begin{array}{c}P_{1} \\
\text { (psia) }\end{array}$ & $\begin{array}{c}P_{1} \\
(\mathrm{kPa})\end{array}$ & $\begin{array}{c}P_{2} \\
\text { (psia) }\end{array}$ & $\begin{array}{c}P_{2} \\
(\mathrm{kPa})\end{array}$ & $\begin{array}{l}T_{\text {evap }} \\
\left({ }^{0} \mathrm{C}\right)\end{array}$ & $\begin{array}{c}T_{\text {evap }} \\
(K)\end{array}$ & $\begin{array}{l}T_{\text {cond }} \\
\left({ }^{0} C\right)\end{array}$ & $\begin{array}{c}T_{\text {cond }} \\
(K)\end{array}$ \\
\hline $\begin{array}{l}\text { Not submerged } \\
\text { in water }\end{array}$ & 16,83 & 116 & 155,52 & 1072 & -23 & 250 & 42 & 315 \\
\hline $\begin{array}{l}\text { Submerged in } \\
\text { water } 1 / 2 \text { liter }\end{array}$ & 14,65 & 101 & 143,57 & 989,6 & -26 & 247 & 39 & 312 \\
\hline Submerged in & 13,63 & 94 & 135,97 & 937,2 & $-27,5$ & 245,5 & 37,2 & 310,2 \\
\hline
\end{tabular}




\section{International Journal of Applied Sciences and Smart Technologies}

Volume 3, Issue 2, pages 203-214

p-ISSN 2655-8564, e-ISSN 2685-9432

\begin{tabular}{l|l|l|l}
\hline water $\frac{3}{4}$ liter & & & \\
\end{tabular}

Table 2. Enthalpy values in the vapor compression cycle for each study variation

\begin{tabular}{lcccccc}
\hline $\begin{array}{l}\text { Condition of the pipe } \\
\text { between compressor and } \\
\text { condenser }\end{array}$ & $\begin{array}{c}P_{1} \\
(\mathrm{kPa})\end{array}$ & $\begin{array}{c}P_{2} \\
(\mathrm{kPa})\end{array}$ & $\begin{array}{c}h_{1} \\
(\mathrm{~kJ} / \mathrm{kg})\end{array}$ & $\begin{array}{c}h_{2} \\
(\mathrm{~kJ} / \mathrm{kg})\end{array}$ & $\begin{array}{c}h_{3} \\
(\mathrm{~kJ} / \mathrm{kg})\end{array}$ & $\begin{array}{c}h_{4} \\
(\mathrm{~kJ} / \mathrm{kg})\end{array}$ \\
\hline Not submerged in water & 116 & 1072 & 384 & 437,3 & 259,4 & 259,4 \\
\hline $\begin{array}{l}\text { Submerged in water 1/2 } \\
\text { liter }\end{array}$ & 101 & 989,6 & 382,82 & 436,0 & 254,9 & 254,9 \\
\hline $\begin{array}{l}\text { Submerged in water 3/4 } \\
\text { liter }\end{array}$ & 94 & 937,2 & 381,90 & 435,1 & 251,9 & 251,9 \\
\hline
\end{tabular}

Table 3. Calculation results of cooling engine characteristics

\begin{tabular}{lcccc}
\hline $\begin{array}{l}\text { Condition of the } \\
\text { pipe between } \\
\text { compressor and } \\
\text { condenser }\end{array}$ & $\begin{array}{c}Q_{\text {in }}=h_{1}-h_{4} \\
(\mathrm{~kJ} / \mathrm{kg})\end{array}$ & $\begin{array}{c}Q_{\text {out }}=h_{2}-h_{3} \\
(\mathrm{~kJ} / \mathrm{kg})\end{array}$ & $\begin{array}{c}W_{\text {in }}=h_{2}-h_{1} \\
(\mathrm{~kJ} / \mathrm{kg})\end{array}$ & $\begin{array}{c}\text { COP } \\
=Q_{\text {actual }} / Q_{\text {out }}\end{array}$ \\
\hline $\begin{array}{l}\text { Not submerged in } \\
\text { water }\end{array}$ & 124,60 & 177,90 & 53,30 & 2,34 \\
\hline $\begin{array}{l}\text { Submerged in } \\
\text { water } 1 / 2 \\
\text { liter }\end{array}$ & 127,92 & 181,10 & 53,18 & 2,41 \\
\hline $\begin{array}{l}\text { Submerged in } \\
\text { water 3/4 liter }\end{array}$ & 130,00 & 183,10 & 53,10 & 2,45 \\
\hline
\end{tabular}

\begin{tabular}{lccc}
\hline Condition of the pipe & $C O P_{\text {ideal }}=$ & Efficiency $=$ & \\
between compressor and & $T_{e} /\left(T_{c}-T_{e}\right)$ & $\frac{\text { COP actual }}{C O P_{\text {ideal }}}$ & refrigerant mass \\
condenser & flow rate $(\mathrm{kg} / \mathrm{s})$
\end{tabular}

\begin{tabular}{llll}
\hline Not submerged in water & 3,91 & 0,60 & 0,002807 \\
\hline $\begin{array}{l}\text { Submerged in water } 1 / 2 \\
\text { liter }\end{array}$ & 3,86 & 0,62 & 0,002813 \\
\hline $\begin{array}{l}\text { Submerged in water } 3 / 4 \\
\text { liter }\end{array}$ & 3,85 & 0,64 & 0,002817 \\
\hline
\end{tabular}

The research data in Table 1 shows that the condition of the pipe (which is located between the compressor and the condenser) is immersed in water, providing different 


\section{International Journal of Applied Sciences and Smart Technologies}

Volume 3, Issue 2, pages 203-214

p-ISSN 2655-8564, e-ISSN 2685-9432

research data than if the pipe is not immersed in water. This means that the water immersion in the pipe affects the working conditions of the cooling machine or in other words affects the characteristics of the cooling machine. It also appears that the volume of water used to submerge the pipe also affects the research data, this also means that the volume of water affects the characteristics of the cooling machine.

If the pipe is not immersed in water, the working temperature of the condenser gives the highest value compared to other conditions (Table 1 and Table 2). If the pipe is immersed in water, the working temperature of the condenser decreases. When the volume of the immersion water is increased or increased in amount, the working temperature of the condenser decreases. This means that the working temperature of the condenser is influenced by the type of fluid and the amount of fluid around the condenser. When the fluid is replaced, the working temperature of the condenser changes and adapts to the new environment, until a new working temperature of the condenser is obtained. For the liquid fluid environment (in this case water) it provides a lower working temperature of the condenser compared to the gas (air) environment. This may be due to: (a) The specific heat of water is greater than the specific heat of air. The greater the specific heat of the fluid around the condenser, the more difficult it is to change the temperature of the fluid around the condenser. The nature of this fluid seems to make the working temperature of the condenser more attracted to the fluid temperature (b) the value of the convection heat transfer coefficient when the heat transfer process takes place between the condenser and water is greater than when it is with air. The greater the value of the convection heat transfer coefficient, the lower the working temperature of the condenser.

The results show that the heat released by the cooling engine $\left(Q_{\text {out }}\right)$ tends to be more when the condenser's working temperature is lower. This is probably because the value of the heat transfer coefficient of water is greater than that of air. The greater the value of the convection heat transfer coefficient, the greater the heat released by the cooling engine to the water. The existence of a pipe that is immersed in water causes the ability of the cooling machine to release heat to be greater. The largest amount of heat released by the cooling engine is when the pipe is submerged in $3 / 4$ liter of water (Table 3 ). 


\section{International Journal of Applied Sciences and Smart Technologies}

Volume 3, Issue 2, pages 203-214

p-ISSN 2655-8564, e-ISSN 2685-9432

The results showed that when the pipe was immersed in water, the working temperature of the evaporator changed (Table 1). Move towards lower temperatures. As it is known that the working temperature of the condenser is directly proportional to the working pressure of the condenser. When the working temperature of the condenser decreases, the working pressure of the condenser also decreases. For the same refrigeration machine, the compressor's ability to suppress refrigerant is certainly not much different. Both when pressing refrigerant from the evaporator to the condenser and when from the condenser to the evaporator when passing through the capillary tube. So when the working pressure of the condenser drops, the pressure of the evaporator also tends to fall. Because the pressure difference between the condenser pressure and the evaporator pressure tends to be constant. So it is understandable if the decrease in working pressure in the condenser causes the working pressure of the evaporator to also decrease. The decreasing working pressure of the evaporator causes the working temperature of the evaporator to decrease as well.

The results showed that when the pipe leading to the condenser was immersed in water, the heat absorbed by the evaporator increased (Table 3). This is understandable because the working temperature of the evaporator is lower. The lower working temperature of the evaporator will cause the ability of the evaporator to absorb heat to be greater because the temperature difference between the working temperature of the evaporator and the temperature of the fluid around it is getting bigger. The largest heat can be absorbed by the evaporator, when the immersed pipe goes to the condenser with a volume of $3 / 4$ liter of water.

The decrease in the working pressure and temperature of the evaporator, in fact has an impact on the work of the compressor in flowing refrigerant (Table 3). The results showed that the work done by the compressor to move refrigerant per unit mass tends to decrease. This provides information that the compressor work tends to "feel" lighter when the working pressure of the evaporator decreases. Compressor work is most "feeling" light when it is located between the compressor and condenser immersed with a volume of liter of water.

Thus, the important information obtained from this research is, when the pipe between the compressor and the condenser is immersed in water, the pressure and 


\section{International Journal of Applied Sciences and Smart Technologies}

Volume 3, Issue 2, pages 203-214

p-ISSN 2655-8564, e-ISSN 2685-9432

working temperature of the condenser decrease. The decreasing pressure and temperature of the condenser also has an impact on the decrease of working pressure and working temperature of the evaporator. The working pressure decreases in the evaporator, causing the compressor work to tend to be lighter. When the pipe leading to the condenser is immersed in water, the working conditions change, with a new equilibrium condition which is the simultaneous result of the work of each component of the refrigeration engine that works with the vapor compression cycle.

The calculation of the actual $\operatorname{COP}_{\text {actual }}$ value is based on the comparison between the calculation of the heat absorbed by the evaporator $\left(Q_{i n}\right)$ and the compressor power used in the cooling machine $\left(\mathrm{W}_{\text {in }}\right)$. If the $\mathrm{Q}_{\text {in }}$ value tends to increase while $\left(\mathrm{W}_{\text {in }}\right)$ tends to decrease, then the resulting COP value tends to increase. Table 3 shows the $\left(\mathrm{COP}_{\text {actual }}\right)$ values for each variation. The highest actual $\mathrm{CO}$ value is when the pipe is immersed in water with a volume of liter, of 2.45 , followed by the condition of the pipe being immersed in water with a volume of liter and without being immersed in water. The order of this $\mathrm{COP}_{\text {actual }}$ values is the opposite of the $\mathrm{COP}_{\text {ideal }}$ value. If the order of $\mathrm{COP}_{\text {actual }}$ values is increasing, then the order of $\mathrm{COP}_{\text {ideal }}$ values tends to decrease.

The value of the cooling engine efficiency is based on the comparison between the $\mathrm{COP}_{\text {actual }}$ value and the $\mathrm{COP}_{\text {ideal }}$ value. The results of this study show that the $\mathrm{COP}_{\text {actual }}$ value tends to increase while the $\mathrm{COP}_{\text {ideal }}$ value tends to decrease. Because efficiency is a comparison between $\mathrm{COP}_{\text {actual }}$ and $\mathrm{COP}_{\text {ideal }}$, the efficiency value will tend to increase. The highest efficiency value of the cooling machine is 0.64 , produced when the pipe is immersed in water with a volume of liter. The lowest efficiency value when the pipe is not immersed in water.

\section{Conclusions}

The results of the study provide the following results:

a. The designed cooling machine can work well and smoothly as desired. The working temperature of the evaporator is able to reach temperatures below $-23^{\circ} \mathrm{C}$, and the working temperature of the condenser is able to reach temperatures above the temperature of the fluid in its environment, above $37^{\circ} \mathrm{C}$. 


\section{International Journal of Applied Sciences and Smart Technologies}

Volume 3, Issue 2, pages 203-214

p-ISSN 2655-8564, e-ISSN 2685-9432

b. The $\mathrm{COP}_{\text {actual }}$ value of the refrigeration machine from the largest to the lowest, respectively, is owned when the pipe located between the compressor and condenser is immersed with full volume of water, full volume of water immersed, and without water immersion, of 2.45, 2. 41 and 2.34.

c. The efficiency values of the refrigeration engine from the largest to the lowest are respectively owned when the pipe located between the compressor and the condenser is immersed with full volume of water, full volume of water immersed, and without water immersion, of $0.64,0.62$ and 0.60 .

\section{References}

[1] K. Anwar, E. Arif, dan W. H. Piarah, "Effects of Capillary Pipe Temperature on Cooling Engine Performance." Mechanical Journal, 1 (Januari 1), 30 - 3, 2010.

[2] Matheus M Dwinanto, Hari Rarindo and Jonri Lomi Ga, "The effect of the dimensions of the capillary tube and the mass of the refrigerant used on the performance of a double evaporator refrigeration machine for fish preservation," Proceedings of the Annual National Seminar on Mechanical Engineering \& Thermofluid IV, 1 (1), 2012.

[3] Said H. I., Abbas, Lita A.Latif, "Experimental study of cooling engine performance in the Mechanical Engineering laboratory, Khairun University, Ternate," Proceedings Annual National Seminar on Mechanical Engineering \& Thermofluid IV, 1 (1), 2012.

[4] Soegeng Witjahjo, "Performance Test of Refrigeration Machines Using LPG Refrigerant," Austenite Journal, 1 (2), 2009.

[5] Wibowo Kusbandono, P.K. Purwadi, "The Effect of the Existence of Fan in the Wood Drying Room on the Drying Time and the Performance of the Electric Energy Wood Dryer," International Journal of Applied Sciences and Smart Technologies (IJASST), 3 (1), 2021. 
International Journal of Applied Sciences and Smart Technologies

Volume 3, Issue 2, pages 203-214

p-ISSN 2655-8564, e-ISSN 2685-9432

This page intentionally left blank 